\title{
Linguistic representation of gender stereotypes in English advertising texts
}

\author{
V. V.Samarina ${ }^{1,}$ T. L. Poliakova ${ }^{2}$ \\ ${ }^{1}$ Kharkiv National Technical University “Kharkiv Polytechnic Institute"; ${ }^{2}$ Kharkiv Petro Vasylenko National Technical University of Agriculture \\ Corresponding author. E-mail: tatyana_kharkov@outlook.com
}

Paper received 28.03.18; Accepted for publication 03.04.18.

https://doi.org/10.31174/SEND-Ph2018-160VI47-13

\begin{abstract}
Within the framework of the communicative-discursive research line, the study of linguistic gender construction in the communicative interaction of individuals in various types of discourse is conducted. A great number and variability of the concepts of masculinity and femininity makes it possible to manipulate them in mass communication discourses, for example, in advertising. The research of advertising discourse reveals gender stereotypes, which are used as a tool for transferring information about the object of advertising and about social reality. The analysis of advertising shows that according to the traditional ideas about the social role of men and women, the construction of images of not only advertising personalities but of the object of advertising itself takes place in modern advertising discourse despite the attempts to neutralize the gender factor.
\end{abstract}

Keywords: advertising discourse, gender, stereotype, representation, masculinity, femininity.

Introduction. The primary focus of gender studies is on the cultural and social factors that determine the public attitude towards men and women, people's behavior resulting from their belonging to male or female sex, a stereotyped idea of male and female qualities - everything that switches the gender issues from the field of biology to the sphere of social life and culture. Thus, manhood and womanhood are considered not as immanent natural factors, but as concepts of culture. There are rather few studies devoted to the analysis of linguistic means of the expression of gender stereotypes in verbal texts, including advertising ones. Therefore, we see it necessary to investigate the means of linguistic representation of gender stereotypes as exemplified in the Englishlanguage advertising texts.

The research subject is advertising texts that represent certain gender stereotypes.

The research object is linguistic and stylistic means of generating gender stereotypes in advertising texts.

The language of advertising is characterized by the dynamism, variability and instability of its vocabulary, and liberality towards literary norms. But, despite its sometimes temporary character, the structural units of the advertising text affect the vocabulary of the language as a whole.

The research relevance is stipulated by the long-felt need to identify the ways of linguistic and stylistic representation of gender stereotypes that are used in modern advertising, as well as the necessity to analyze linguistic means of advertising texts in order to identify the patterns of the advertising text according to gender stereotypes.

The purpose of the research is to conduct a linguistic and stylistic analysis of gender stereotypes.

The research material includes 430 advertisements taken from illustrated magazines "Cosmopolitan", "Elle", "ForbesLife", "Glamour", "Runway", "Seventeen" that were published in the UK, Canada and the United States from 2007 to 2017, as well as the advertisements taken from Internet resources.

Modern advertising, as part of culture, is becoming an integral part of our life. It forms a model of human behavior, influences life values and is a source of information in the processes of socio-cultural dynamics of modern society $[2, \mathrm{p}$. $28 ; 4$, p. $19-20 ; 5$, c. $13 ; 7$, p. 3].

Advertising has a socio-psychological impact on a person, but its perception by opposite sexes is different. The effect arises due to the color, visual and acoustic clues, and the texts used in the advertisement. Effective impact is impossible without careful planning of the audience the advertising text is intended for. Advertising, created "in general", without taking into account the peculiarities of the people - con- sumers of goods and advertising, their wishes, preferences and opportunities, is unlikely to be effective. In general, the linguistic competence is influenced by a huge number of different factors, so advertising texts are created with due regard to the social status, profession, age, sex [5, p. 26-29].

The research, the focus of which is gender, is a social and cultural construct associated with attributing certain qualities and standards of behavior to a person on the basis of his or her biological sex. It is a relatively new field of humanitarian knowledge. The first works in this field appeared in the West. As for our domestic linguistics, the first regular studies on this subject began to be conducted only in the late 80's early 90's. And since the mid 90's they started to develop at a rapid pace. At present, we can speak of the emergence of another new branch of national linguistics - linguistic gender studies (or gender linguistics) [1].

Formation and intensive development of gender studies in linguistics is associated with changes in the scientific paradigm in the humanities under the influence of postmodern philosophy. New interpretation of categorization processes, the refusal to accept the objective truth, the interest in the subjective, in the private life, the development of new personality theories, the theory of social constructivism in particular, have led to the reconsideration of the scientific principles of studying the categories of ethnicity, age and sex, which were previously interpreted as biologically deterministic. The new approach also requires the use of new terminology that more accurately corresponds to the methodological purposes of the researchers. It became the reason for the introduction of the term gender called upon to emphasize the socially constructed nature of sex, its conventionality, institutionality, and ritualization. This approach naturally stimulated the study of linguistic mechanisms of gender manifestation in language and communication. The feminist criticism of language, which is considered to be one of the components of postmodern philosophy, has also urged on the scientists to this field [6, p. 154-161].

A.P. Martyniuk interprets the gender stereotype as an idea about the attributes that are characteristic/non-characteristic to an individual who is categorized as a man or a woman by the society and which is historically determined, minimized, typified and structured in the form of a frame formed in the collective consciousness of a certain linguocultural society. The researcher also interprets the standard as an idea of the attributes that are desirable/undesirable for this individual [3, p. 47].

In the works devoted to studying masculinity, the attributes of success include a high income level, a high social status, employment in certain spheres of activity, for example, in the financial business $[1 ; 9$, p.107-116]. 
Due to the fact that since their childhood men have had the qualities that help them to achieve high positions, they have a higher social status, and, hence, higher incomes than women. Therefore, premium-class goods (cars, real estate, cruises, expensive women's jewelry) should be advertised mainly for male audience, since, as a rule, such purchases are financed by a man.

\section{Zenith}

"Whatever does not destroy me makes me stronger." Friedrich Nietzsche [3, c. 47].

In the following example, let's have a look at real estate advertising. If the advertisement is directed at the male audience, then it will be wise to indicate the actual benefits: district, apartment layout, garage availability, cost.

2. The home seamlessly transitions from indoor to outdoor living, which features 8,245 square feet under air, 12,509 square feet under roof and a 1,775-square-foot rooftop terrace positioned to maximize the golf and water views ..... Additional features include LEED Gold certification, Solar to $18 \mathrm{KW}$, Tesla backup batteries/whole house generator, Outdoor Phantom screens, Full guest casita with lanai, Imported glass Belgian stairway, Elevator and Two 2-car garages [8].

The analysis of this advertising text allows us to conclude that this model is aimed at the male gender stereotype (technical terminology, peculiarities of the vocabulary, syntax and actual material inherent in the male language).

If you need to influence a woman, you can simply show colorful photos of a comfortable, cozy apartment, as well as give some information about the availability of a playground, a kindergarten, a school, a polyclinic, shops which are situated nearby.

3. Key location within walking distance to miles of coastal trails for hiking or biking. New paint, window and floor coverings throughout most of the house. Roof was recently installed. Easy access to shops, restaurants and all that charming downtown Fort Bragg has to offer [8].

Advertising of household appliances and office equipment, cars, aimed at men, should be clear and accurate. These products must be functional, high-quality, reliable, and the price must match their characteristics.

4. The best place to put a Da Vinci: on your wrist.

Da Vinci Chronograph. Ref. 37 64: Sometimes you have to break with convention to progress. In the case of this watch we did so several times. ... And thanks to the flyback function, it starts again in the blink of an eye. Even Leonardo would probably have spared it a wrist. IWC. Engineered for men [3, c. 43].

The studies in the field of marketing show the power of certain ideas, inspired by advertising [8, p. 24-30]. Indeed, the image of a car created by mass culture can "convince" its owner of the exceptional nature of the status of a successful person who could afford it: Cruze exterior design gives you the presence of a more expensive car with its beveled hood; Mazda 6. Impulse Line. Big charm of a car configuration. In this context we can assume that the car is the strongest means of a person's self-affirmation in a modern society of consumption, since when buying a car, people acquire not only a means of travel, but also something else, for example, freedom, dream, status, identity.

In our opinion, the image of a car in mass culture is based on two basic concepts - freedom and power, which the creators of advertising appeal to. Purchasing a car, a person, in our case, a man, gets freedom (freedom of movement), and possession of a car is associated with getting control / power (control over the road). Advertising transmits the values of these archetypes - power, prestige, wealth, victory, thus, forming people's needs.

5. Update your status with status. You'll want to follow yourself. Now trending in your garage [9].

Associative chains "car - freedom", "car - power" are being built.

6. Focus ST delivers true performance in every aspect, combining with power precision, strength with agility, force with finesse;

...the exhilaration and liberation from experiencing the emotion of motion [9].

Appealing to subconscious archetypal ideas about the "ruler", "hero", "winner", mass culture tries to force a modern person to believe that with the purchase of a car, he will acquire something more than just a vehicle.

Another aspect that needs to be taken into account when drawing up an advertisement is the tendency of a woman to speak in equivoques. This is a consequence of the fact that the woman was dependent on her husband and could not speak directly, so she expressed her wishes with hints. Modern men cannot always understand why women do not say directly what they want. Therefore, the use of implicit, concealed information in advertising is acceptable for women, but it is undesirable for men because the man better perceives explicit directions for actions.

7. Different day, different flow, different protection (Always) [6, c. 84].

The anaphora used intensifies and emphasizes the meaning of what is being said. Typically, the anaphoric beginning of the advertising text contains the name of the advertised firm, product, services, etc. This figure of speech is intended to place emphasis on the object advertised, to direct the audience`s attention, in this case - the woman, to it.

The woman is primarily interested in the ease of use, design, and "fashion".

We should not forget that women are inclined to exaggerate and perceive information emotionally, while men take what is being said literally. For him, every phrase should be extremely clear and reliable.

8. Don't just volumize, millionize your lashes in Extra Black (L'OREAL) [7, c. 8].

The basis of hyperbole is always the element of a certain absurdity, sharp contrast to common sense or social experience, intentional exaggeration of the properties of the object, which increases the expressiveness and gives the expression the emphatic character.

9. "Even after 32 washes, my color looks pure and luminous. It's almost like I just colored my hair." Eva Longoria

"As a colorist, I recommend EverPure. Its rich lather respects your hair fiber and its Anti-Fade System protects your color." Christophe Robin L'oreal Paris Color Expert

L'oreal ${ }^{\circledR}$ Paris Hair Expertise

Because we're Worth It [5, c. 5].

There is a great number of emotional and appraisive epithets which are often used in the superlative degree, since they help to make the arguments more vivid and illustrative: ultraglamorous, secular, radiant, exclusive, star, elegant, magical, best, leading, sexy, brilliant, extra resistant, luxury. 10. Rich colour, rich compliments (PERFECT 10) [1, c. 44]. 11. Enjoy sheer gloss color, soft moisturizing and a delicious, non-sticky feel (COVERGIRL) [4, c. 118].

12. FRESHLY SQUEEZED (DKNY Be Delicious) [4, c. 44].

The use of metaphors contributes to the perfect form thanks to figurative complements: Freshly Squeezed - a combination of flower and sweet apple fragrance in the bottle which resembles a red-ripe fruit (an apple): DKNY Fresh- 
ly Squeezed - Be delicious! Linguistic mechanisms are able to provide a high depth of exposure on the consumer by creating a certain emotional effect.

Using repetitions of words and phrases helps an advertiser to transfer all necessary information to the reader, mentioning the most important characteristics several times:

13. Skin looks more refined, more luminous...more luxuriously renewed (Chanel) [2, c. 228].

Thus, the advertising text becomes brighter and more significant for recipients. It becomes more attractive and interesting, leading to the desire to obtain the product advertised.

The significance of the youth as one of the most important components of the modern way of life, as the "age status quo" is intensified by the factor of the addressee prestige these are the appeals of celebrities, who should be imitated: 14. "This is the best cream I've ever tried!" - Salma Hayek (Olay) [4, c. 129].

15. "It's almost like I just colored my hair", - Eva Longoria (L 'oreal) [1, c. 57].

The idea of the "eternal youth" is promoted by mass culture very actively. The way of life which involves not only biological youth, but also the youth, supported artificially is being advertised. There are objective reasons for the popularity of the youth cult. A whole industry of beauty, rejuvenation has been created, ranging from simple beauty products to plastic surgery. The cult of youth as a value of the modern consumption society is very well sold and commercially reasonable.

16. New pro-X resignals your skin by increasing its surface turnover and repairing the moisture barrier so it performs more like it did when it was younger. What you see in a very short time is a measurable reduction in the look of wrinkles (PROX) [1, c. 114].

Comparison stimulates customers` imagination, depicting the best effect of using the product, as well as obtaining the desired result in a short time and without great efforts.

It should be mentioned that the so-called glamorous discourse actively uses elements of scientific terminology and pseudo-terminology, claiming to be true. Indeed, when using this kind of vocabulary, the authority of the statement is emphasized. There is an appeal to supposedly scientific achievements, capable of doing miracles.

Since the advertising text is a collection of lexical units in which a particular gender stereotype is encoded and which is aimed at a particular gender stereotype, then, it is a means of reinforcing and adopting existing gender stereotypes. Advertising, which is manipulative communication, aims to influence the recipient in such a way as to motivate him to take necessary actions.

For further study of the linguistic features of gender stereotypes, it is relevant to conduct the analysis of advertising texts representing a mixed gender stereotype.

\section{REFERENCES}

1. Горошко Е. Гендерная проблематика в языкознании/Е. Горошко. Реж. доступа: http://www.owl.ru/win/books/articles/goroshko.htm.

2. Крутько Т. В. Англомовна реклама у віртуальному просторі : дис. ... канд. філол. наук: 10.02.04 / Крутько Тетяна Валеріївна. - Рівне, 2006. -216 c.

3. Мартинюк А. П. Конструювання гендеру в англомовному дискурсі / А. П. Мартинюк. - Харків: Константа, 2004. - 292 с

4. Мельник П. Ю. Реклама та ії використання в умовах реалізації соціокультурного підходу / П. Ю. Мельник // Іноземні мови. 2004. - № 4. - C. 19-24.

5. Самарина В. В. Немецкоязычный рекламный дискурс: прагматический, когнитивный и лингвостилистический аспекты : дис. ... канд. филол. наук : 10.02 .04 / В. В. Самарина. - Х., 2010. $-210 \mathrm{c}$.
6. Таннен Д. Ты меня не понимаешь! Почему женщины и мужчины не понимают друг друга / Д. Таннен. - М.: Віче Персей ACT, 1996. $-432 \mathrm{c}$.

7. Флягина И. А. Реклама в формировании социокультурных образов/И. А. Флягина//Социальная коммуникация и социальное управление в экоантропоцентрической и семиосоциопсихологических парадигмах: в 2-х кн./[отв. ред. Т. М. Дридзе].-М.: Издательство Института социологии РАН, 2000.-Кн. 2.-С. 3-24.

8. Bockmiller R. Automobile / R. Bockmiller // How Products Are Made: An Illustrated Guide to Product Manufacturing / ed. N. Schlager. Detroit: Gale Research, 1994. - C. 24-30.

9. Hofstede G. Lokales Denken, globales Handeln. Kulturen, Zusammenarbeit und Management / G. Hofstede. - München: Beck, 1997. $-420 \mathrm{~s}$.

\section{REFERENCES}

1. Goroshko H. Gender problems in linguistics / H. Goroshko. - Retrieved from http://www.owl.ru/win/books/articles/goroshko.htm.

2. Krutko T. V. English advertising in the virtual space: dis. ...PhD (Philology): 10.02.04/Krutko Tetiana Valeriivna.-Rivne, 2006.-216 p.

3. Martynyuk A. P. Gender construction in English discourse: [monograph] / A. P. Martynyuk. - Kharkiv: Konstanta, 2004. - 292 p.

4. Melnik P. Yu. Advertising and its use in the conditions of implementation of socio-cultural approach / P. Yu. Melnik // Foreign languages. - 2004. - № 4. - P. 19-24.

5. Samarina V. V. German advertising discourse: pragmatic, cognitive and linguostylistic aspects: dis. ...PhD (Philology): 10.02.04 / V. V. Samarina.-Kharkiv, 2010.-210 p.

6. Tannen D. You just don`t understand! Why men and women do not understand each other/D. Tannen.-Moscow: Viche Persey AST, 1996. $-432 \mathrm{p}$.

7. Flyagina I. A. Advertising in the formation of socio-cultural images / I. A. Flyagina // Social communication and social management in eco-anthropocentric and semiosociopsychological paradigms: in 2 books. / [Ed. T. M. Drydze].-M.: The Institute of Sociology of the Russian Academy of Sciences, 2000.-Book 2.-P. 3-24.

\section{LIST OF ILLUSTRATIVE MATERIAL}

1. Cosmopolitan. - № 6. $-2011 .-237 \mathrm{p}$.

6. Runway. - № 4. $-2010 .-210$ p.

7. Seventeen. - № 5. -2012 . $-202 \mathrm{p}$.

8. http://www.mendocinoagent.com

3. ForbesLife, December 2007

4. Glamour. - № 11. -2013 . -185 p.

9. https://www.ford.com/cars/focus/

\section{Лингвистическая репрезентация гендерных стереотипов в английском рекламном тексте}

\section{В. В. Самарина, Т. Л. Полякова}

Аннотация. В рамках коммуникативно-дискурсивного направления проводится изучение лингвистического конструирования гендера в коммуникативном взаимодействии индивидов в различных видах дискурса. Множественность и изменчивость понятий мужественности и женственности делает возможным манипуляцию ими в дискурсах массовой коммуникации, например, в рекламном. Исследования рекламного дискурса выявляют гендерные стереотипы, которые используются как инструмент передачи информации об объекте рекламирования и о социальной действительности. Анализ рекламы показывает, что в соответствии с традиционными представлениями о социальной роли мужчин и женщин, в современном рекламном дискурсе происходит конструирование образа не только рекламных персонажей, но и самого объекта рекламирования несмотря на попытки нейтрализации гендерного фактора.

Ключевые слова: рекламный дискурс, гендер, стереотип, репрезентация, мужественность, женственность. 